Dr. Posewitz refers to recent formations in the Island of Banka, off the east coast of Sumatra. This is an instance of an island, undisturbed by volcanic activity, in which erosion and denudation are constantly at work forming the coast. Herr Strass has a paper in the same number dealing with the statistics of emigration from Germany between 1871 and 1884 . No. 8, which is the last published, contains a report by Herr Pohle on the expedition sent in I884 to that part of the coast of SouthWestern Africa between the Orange River and Walfisch Bay, which came at that time into the possession of Herr Luideritz. The expedition was intended mainly to ascertain what useful minerals existed in the new territory, and also to study its fauna, flora, and soil. The report is one of considerable length, and deals with all these points, The paper on the forests of North America is based on Prof. Sargent's report, contained in the nin:h volume of the United States Census Report for I884.

THE Proceedings of the Royal Geographical Society for August contain several papers of interest. In "Recent Portuguese Explorations in the Zambezi Region" two journeys are described-one between the Zambezi and Pungué, the other between Tete on the Zambezi and Makanga. Mr. J. W. Wells, in a short paper, contributes some information on the delta of the Tocantins, in Brazil, and there is also a summary (the first, we believe, that has appeared in English) of the Von den Steinen exploration of the Xingu. The resulis of this expedition confirm the conclusion with regard to the geology of the interior of Brazil arrived at by the late Prof. Hartt, and by Mr. Wells, that south of the Amazon valley the whole interior of Brazil was at one time an immense plateau, and that the changes which it has undergone are due to water denudation. But the most important communication in this month's Pro. ceidings is the report of the measures adopted by the Council of the Society for the improvement of geographical education. These are of two classes, to be carried out with the co-operation or assistance of the two Universities and the Education Office respectively. Under the first head the Council offer to appoint and pay a lecturer or reader in geography to deliver courses of lectures at both Universities, arranged so as to suit students in the Honour Schools; or, in the aliernative, to join with both Universities in appointing and paying a reader in geography. In addition, the Council offers to contribute the funds for an exhibition. In connection with the Education Office, the Council offers various prizes in money and books to pupil teachers. Further, a donation of $30 l$. for the present year is made in aid of the geographical lectures in the University extension courses; copies of the Proceedings are to be sent to various public school libraries, and travellers and geographers are to be put in communication with the head masters of public schools. The proposal for a readership in geography at the Universities is obviously the most important of these, and the result of the communications now passing between the President and the Vice-Chancellors will be awaited with much interest.

The last number (Bd. xxix. No. 4) of the Mittheilungen of the Geographical Society of Vienna has for its first article a discussion, by Prof. Penck, of the proportion of the areas of land and water on the surface of the globe. The writer gives at the outset an interesting sketch of the history of the subject, and of the various theories which have prevailed from time to time on the subject, beginning with Columbus, who thought the proportion of land to water was as 6 to I. Starting from the grenerally accepted proportion of Wagner as that of $I$ to $2 \cdot 76$, Prof. Penck advances various reasons for believing this to be unreliable, especially our ignorance of the regions around the North and South Poles. The blanks on our maps are still too numerous and important to permit of any reasonable approach to accuracy being made. Dr. Paulitschle writes on the hydrography of the Upper Webi, one of the two hydrographic problems of the Somâli peninsula, the other being the Juba, which Capt. Cecchi calls complicata e misteriosa. The writer appears to throw much light on the first from his own explorations. He thinks we must seek the source of the Webi in or e of the lakes of Gurage. Prof. Blumentritt criticises that part of Dr. Montano's recent work on the Philippines which deals with the ethnology of Mindanao. Accepting for his present purpose (though he refuses to do so as a general proposition) Montano's division of the inhabitants into three main heads-Negritos, Indonesians, and Malays - he advances various reasons for holding that that writer does not arrange the tribes of Mindanao accurately under these heads. These are based chiefly on the languages; but if it does nothing else, the paper demonstrates the wide knowledge which Prof. Blumentritt possesses of these regions. Indeed, for years past he has made every department of research connected with the Philippines his own, until now he is without a living rival.

A REPORT has been received at the Hydrographic Depariment of the Admiralty from Commander Moore, of the surveying-vessel Ramóler, relative to the existence of an island lying between L'Echiquier group and Durour Island, recently discovered by Mr. Allison, commanding the British steamer $F_{e} i$ Lung, when on the passage from Sydney to Shanghai. This island is covered with trees, and appeared to be 2 or 3 miles long in a north-west and south-east direction, and IOO to 150 feet in height. Both Durour Island and this were visible at the same time from the Fei Lung when passing between them. The approximate position as reported is lat. $1^{\circ} 25^{\prime} \mathrm{S}$., long. $143^{\circ} 26^{\prime} \mathrm{E}$. The Hydrographer to the Admiralty says that, unless the positions of the islands already on the chart are more inaccurate than they are believed to be, there is little doubt that the island now reported is a new discovery.

THE August number of the Scottish Geographical Magazine contains a translation of Col. Fontana's lecture on the Patagonian Andes to the Argentine Geographical Institute, describing his recent journey from Chubut to the slopes of the Andes. The latter are mentioned with great enthusiasm: they teem with fertility, and Nature is as exuberant there as farther north in the Gran Chaco. Finally, the sub-Andean portions of Patagonia are described as the country of the future, being another added to the long list of countries of the future.

In tome $\mathrm{x}$. fascicule 5, of the Bulletin of the Geographical Society of Antwerp, M. van den Gheyn discusses the question whether there is unity, duality, or plurality of races in Australia, and comes to a conclusion in favour of unity. He thinks that the differences found amongst them are to be explained by mixture with the Indonesians on the one side and the Polynesians on the other.

THE French Minister of Public Instruction has intrusted M. Alfred Marche with a mission to the Marianne Islands to study the geography, natural history, anthropology, and ethnography of the Archipelago.

\section{THE AUGUST PERSEIDS}

$\mathrm{THE}$ shower of Perseids has been a fairly conspicuous one this year notwithstanding the somewhat unfavourable circumstances attending the display. On the nights of August 9, 10, and II the nearly-full moon was visible during the greater part of the time available for observation, and robbed the phenomenon of its chief prominence during the evening hours. Those, however, who continued to watch the heavens until after the moon set on the early morning of the I Ith must have been rewarded by a tolerably rich exhibition of meteors. The number observable by one person fell little short of 100 per hour, and this rate compared with similar observations in past years proves the late display to have fully maintained its decided character. Numerically this shower of Perseids cannot be placed in the same category as the brilliant meteoric storms of November I3, 1866, and November 27,1872 and 1885 , but it must be remembered that the August shower is one which returns anmually, and apparently without much variation in its leading features. Its frequent and regular appearances compensate for whatever it lacks in other respects, and it yields many fine meteors of the same type as the Leonids, flashing out with remarkable swiftness, and projecting lines of phosphorescence upon the background of the sky.

The importance of watching every recurrence of the leading meteor showers is acknowledged on all hands, for if we would successfully trace out the modern history and developments of these wonderful systems we must first carefully secure the materials to form the basis of such investigations.

With reference to the shower of Perseids this year, the observations were much interrupted by cloudy weather. Preparation had been made here to commence a look-out during the last week in July for avant-couriers of the stream, but the nights were persistently overcast, and it was not until August 2 that a good view was obtained. Clouds were, it is true, somewhat prevalent before midnight, but afterwards the firmament became very clear, and it remained uniformly serene until daybreak. 
Watching the eastern sky between Ioh. and $14 \frac{1}{2} h$., I counted 50 meteors, and of these 12 were Perseids displaying the normal features. The radiant-point was, at $33^{\circ}+55^{\circ}$, not very sharply defined. Some of the best observed paths were slightly discordant, and gave the impression that the focus of divergence was diffused over an area of $3^{\circ}$ or $4^{\circ}$ diameter.

The following night was cloudy, but August 4 came in very clear, and 58 meteors were seen between roh. and $14 \frac{3}{4} \mathrm{~h}$. Amongst these were 12 Perseids, and the radiant-point, more contracted and definite than on the 2nd, was now at $37^{\circ}+57^{\circ}$, having increased $4^{\circ}$ in R.A. in the interim of 48 hours. The shower exhibited no increase in numbers between the 2 nd and 4th; indeed, there appeared to have occurred a slight falling off on the latter date. But on the 4th I saw a duplicate shower of Perseids, the companion radiant being at $48^{\circ}+43^{\circ}$, between $\alpha$ and $\beta$ Persei, and this position was accurately indicated from seven paths.

A cloudy period supervened between the 4 th and Ioth, but on the latter night the sky was very clear throughout, though the moon was ap until $13 \mathrm{~h}$. $30 \mathrm{~m}$. Between $10 \mathrm{~h}$. and $14 \frac{1}{2} \mathrm{~h}$. I observed 152 meteors, though the watch was not persistent during that interval. The number seen included $\mathbf{1 2 2}$ Perseids with a radiant at $44^{\circ}+57 \frac{1}{2}^{\circ}$. At $\mathrm{I} 3 \mathrm{~h}$. 6 meteors were noted within 20 seconds, and after the moon had fallen below the horizon the shower developed into one of considerable activity. Between $14 \mathrm{~h}$. and $14 \mathrm{~h}, 15 \mathrm{~m}$. I counted $\mathbf{2 2}$ meteors, so that they were coming at the rate of about 90 per hour for one observer. Some of them were unusually bright. At $13 \mathrm{~h} .34 \mathrm{~m}$. a splendid Perseid appeared in the northern sky, pursuing a path of $13^{\circ}$ from $77^{\circ}+67^{\circ}$ to $\operatorname{II} 1^{\circ}+67^{\circ}$. It lit up the whole heavens with a momentary flash, and left a luminous streak, near the end of its path, that remained visible to the eye for nearly 4 minutes. This was by far the most conspicuous meteor seen during the night, and it will probably have been recorded at many other places.

On August in the sky was partly clear between $10 \frac{1}{2} \mathrm{~h}$. and II $\frac{3}{4} \mathrm{~h}$, and 22 meteors were noted, including I5 Perseids from $47^{\circ}+571^{\circ}$. Thus the position of the radiant showed a still further displacement towards the east. The shower had declined greatly since the preceding night, and offered little attraction in the presence of the bright moonlight.

The shifting radiant of the Perseids forms one of the most curious and important details of its display. I first mentioned this feature in NATURE, vol, xvi. p. 362, and have been much interested in reobserving it on many subsequent occasions. Comparing the four positions determined this year, and one obtained on August 13, I885 (NATURE, vol. xxxii. p. 415), the character of the displacement is well shown, and corroborates the figures given in the Monthly Notices, December I884, pp. $97^{-8}:-$

\begin{tabular}{|c|c|c|c|c|c|c|c|}
\hline ugust & & & $33+5$ & & & & ieteors \\
\hline & 4 & $\ldots$ & $37+57$ & $\ldots$ & $\ldots$ & 12 & . \\
\hline 10 & $\ldots$ & $\ldots$ & $44+57 \frac{1}{2}$ & $\ldots$ & $\ldots$ & 122 & ," \\
\hline II & . & $\ldots$ & $47+57 \frac{1}{2}$ & $\ldots$ & $\ldots$ & I 5 & . \\
\hline I3 & $\begin{array}{ll}3 & \ldots\end{array}$ & $\ldots$ & $5 \mathbf{I}+58$ & $\ldots$ & $\ldots$ & 6 & ," \\
\hline
\end{tabular}

On the whole the recent shower may be justly regarded as one fully answering to expectation. It has been quite equal, if indeed it has not surpassed, the Perseid displays as I observed them in $1869,1871,1874,1876,1877,1878$, and 1880 . It is, however, somewhat difficult to institute perfectly fair comparisons. The circumstances affecting two displays are rarelygif ever identical. In some years the shower escapes suitable observation owing to cloudy weather just at the important time. In others moonlight neariy obliterates it. We must also consider that, as the main richness of the stream is limited to a short interval, it will occasionally elude us by occurring in daylight. These varying conditions and hindrances render it unsafe to draw conclusions as to the relative aspect of the annual displays unless the evidence is very complete and satisfactory.

It is well known that an unusually large number of minor systems occur simultaneously with the August Perseids. 'The positions of many of these are now ascertained with considerable precision. The labours of Heis and Schmidt, ably supplemented by Greg, Alex. Herschel, Zezioli, and others, have furnished a multitude of observations which are satisfactorily accordant as to many of the secondary showers of the epoch. The results obtained in the present year have been extremely productive of tenuous radiants. I select five of these as affording instances of very definite showers :--

\begin{tabular}{|c|c|c|c|c|}
\hline Yo. & 1886 & Radia & $\begin{array}{c}\text { No. of } \\
\text { meteors }\end{array}$ & Features \\
\hline & dily & & & \\
\hline & & & $\ldots$ II & \\
\hline & . & 48 & . IO & ks. \\
\hline & 3I-Aug. 2 & $\begin{array}{ll}\ldots & 2 b+42 \\
\ldots & 20+58\end{array}$ & $\begin{array}{ll}\cdots & 0 \\
\ldots & 7\end{array}$ & Swift, streal \\
\hline
\end{tabular}

Nos. I and 2 I observed also in August 1885 (see NATURE, vol. xxxii. p. $\left.4{ }^{1} 5\right)$, when I derived their radiants at $292^{\circ}+52^{\circ}$ and $345^{\circ}+53^{\circ}$ respectively. No. 3 , between $\alpha$ and $\beta$ Persei, I observed in July and August I877, and again on July 23-25, 1884 (Monthly Notices, December 1884, p. 107): No. 4, near $\gamma$ Andromedæ, has also been pre-observed here in August 1877 and 1879 ; and No. 5 represents the Cassiopeiads, which have long been known as a pronounced companion shower to the Perseids.

The position No. 2 at $350^{\circ}+51^{\circ}$ lies between Cassiopeia and Lacerta. It was the most prominent of all the minor streams of the August epoch in 1885, and in 1877 I had observed it well hoth in July and August. It has also been noticed by many others in recent years. Taking an average of fifteen different observations the radiant comes out at $350^{\circ} \cdot 2+52^{\circ} \cdot \mathrm{r}$. This particular shower, by its increasing activityıduring the past few years, appears to have supplanted Mr. Greg's Lacerlids at $335^{\circ}+52^{\circ}$, which have evidently not maintained their former strength. It is probable also that during the period of $\mathrm{Mr}$. Greg's researches this August shower at about $350^{\circ}+52^{\circ}$ was comparatively quiescent, for there is no reference to it in his catalogue of 1876 . The same may also be said of the system of Cygnids at about $29 \mathrm{I}^{\circ}+5 \mathrm{I}^{\circ}$ (near $\theta$ Cygni). Possibly, however, the latter may have been formerly confused with the Draconids (= Greg, No. 78). In the "Annuaire pour l'an I885, publié par le Bureau des Longitudes" I find that two of the chief showers accompanying the Perseids on August 9-I4 are stated as at $345^{\circ}+50^{\circ}$ and $294^{\circ}+52^{\circ}$. My recent observations just described confirm this pair of showers in the most definite manner, and they will doubtless be similarly corroborated wherever systematic observations of the Perseids are conducted.

\section{W. F. DENNING}

\section{THE SWISS SOCIETY OF NATURAL. SCIENCES}

THE annual meeting for this year of the Suiss Society of Natural Sciences opened at Geneva on the roth instant under the presidentship of Prof. Louis Soret. This precursor of all itinerant scientific societies was founded in 1815 in Geneva, and the present is its seventh meeting in the city of its birth. The members and visitors were received on the evening of the 9th in the salons of the celebrated Palais Eynard, which, after being long closed, were opened specially for the occasion. After the presidential address on the Ioth, a new committee for the forthcoming period of six years was appointed, with its seat at Berne, the next meeting was fixed to take place at Frauenfeld, in Thurgau, and Prof. Grubenmann was elected president.

Prof. Soret in his address first referred to the advantages offered by Geneva to men who have taken science for their vocation, and then, under the title of "Des impressions réitérées," developed a series of new and original ideas on æestheticism analysed by the man of science. 'The repetition, he said, of the same design, whether in a symmetrical form, or in lined designs, such as we see in tapestry, furniture, or buildings, whether of the same dimensions, or of dimensions regularly decreasing, gives an agreeable impression. It is the same with regular curves, but the æsthetic sensation dwells less in the sensation itself than in the intuition which it gives us of a law. This applies not only to form, but also to sound and to colours. Developing these ideas, M. Soret insisted on the part played constantly by repetitions and similitudes because they evoke by intuition the idea of a law.

II. Marcel Deprez then read a paper on the transmission of force by means of electricity, in which he described his recent experiments between Creil and Paris and the results. M. Rilliet, of Geneva, read the report of a commission appointed to investigate the depth to which light penetrates water. Dr. Heim, of Zurich, read a paper on the deformation of fossils in mountains. He described the modifications which rocks undergo in form even after induration. Under the enormous pressure of the rocks above they may become laminated without any visible solution of continuity in the mass, or any rupture. 